Article

\title{
Highly selective production of phenol from benzene over mesoporous silica-supported chromium catalyst: Role of response surface methodology in optimization of operating variables
}

\author{
Milad Jourshabani a, Alireza Badiei a,b,*, Negar Lashgari a, Ghodsi Mohammadi Ziarani c \\ a School of Chemistry, College of Science, University of Tehran, Tehran, Iran \\ b Nanobiomedicine Center of Excellence, Nanoscience and Nanotechnology Research Center, University of Tehran, Tehran, Iran \\ c Department of Chemistry, Faculty of Science, Alzahra University, Tehran, Iran
}

\section{A R T I C L E I N F O}

Article history:

Received 23 April 2015

Accepted 18 May 2015

Published 20 November 2015

\section{Keywords:}

Mesoporous silica

Chromium/SBA-16 catalyst

Benzene hydroxylation

Phenol

Response surface methodology

\begin{abstract}
A B S T R A C T
$\mathrm{A} \mathrm{Cr} / \mathrm{SBA}-16$ catalyst was prepared using $\mathrm{Cr}\left(\mathrm{NO}_{3}\right)_{3}$ as a precursor and mesoporous silica SBA-16 as a support via a simple impregnation method. The catalyst was characterized using wide-angle X-ray diffraction (XRD), low-angle XRD, $\mathrm{N}_{2}$ adsorption-desorption, transmission electron microscopy, and ultraviolet-visible spectroscopy. The catalyst activity was investigated in the direct hydroxylation of benzene to phenol using $\mathrm{H}_{2} \mathrm{O}_{2}$ as the oxidant. Various operating variables, namely reaction temperature, reaction time, amount of $\mathrm{H}_{2} \mathrm{O}_{2}$, and catalyst dosage, were optimized using central composite design combined with response surface methodology (RSM). The results showed that the correlation between the independent parameters and phenol yield was represented by a second-order polynomial model. The high correlation coefficient $\left(R^{2}\right)$, i.e., 0.985 , showed that the data predicted using RSM were in good agreement with the experimental results. The optimization results also showed that high selectivity for phenol was achieved at the optimized values of the operating variables: reaction temperature $324 \mathrm{~K}$, reaction time $8 \mathrm{~h}, \mathrm{H}_{2} \mathrm{O}_{2}$ content $3.28 \mathrm{~mL}$, and catalyst dosage 0.09 g. This study showed that RSM was a reliable method for optimizing process variables for benzene hydroxylation to phenol.
\end{abstract}

(C) 2015, Dalian Institute of Chemical Physics, Chinese Academy of Sciences. Published by Elsevier B.V. All rights reserved.

\section{Introduction}

Phenol is an important chemical intermediate in the manufacture of many petrochemicals, agrochemicals, polymers, and plastics $[1,2]$. Global production of phenol is mainly performed using the well-known cumene process, but it has disadvantages such as low yields and high energy expenditure, especially in the distillation steps. Moreover, the utility of this process depends on the market demand for the by-product acetone [3] Because of the commercial importance of producing phenol without any by-products, there is therefore much interest in direct oxidation of benzene to phenol as an alternative route, using various oxidants such as $\mathrm{N}_{2} \mathrm{O}$ [4,5], $\mathrm{O}_{2}$ [6], and $\mathrm{H}_{2} \mathrm{O}_{2}$ [7]. The use of molecular oxygen is limited, because it leads to destruction of the aromatic ring, therefore the selectivity for phenol decreases. Although $\mathrm{N}_{2} \mathrm{O}$ performs well in benzene hydroxylation, deactivation of the catalyst by heavy coke formation is a problem [8]. $\mathrm{H}_{2} \mathrm{O}_{2}$ is increasingly being used as the oxidant, because it is a green oxidant and the process is simple. Recently, much research has focused on the incorporation of transition metals such as $\mathrm{Fe}, \mathrm{V}, \mathrm{Cu}$, and $\mathrm{Co}$ into various supports to improve the catalytic performance in benzene hydroxylation to phenol [9]. Song et al. [10] reported that a catalyst consisting of $\mathrm{VO}_{2}$ supported on multiwalled carbon nanotubes gave $23.7 \%$

* Corresponding author. Tel: +98-216-1112614; Fax: +98-216-6405141; E-mail: abadiei@khayam.ut.ac.ir 
benzene conversion and a phenol selectivity of $93.5 \%$. In another study, $\mathrm{Fe}_{3} \mathrm{O}_{4}$ supported on CMK-3 gave $18 \%$ benzene conversion with a phenol selectivity of $92 \%$ [11]. It has been reported that $\mathrm{V}$ supported on mesoporous carbon nitride $\left(\mathrm{V} / m p-\mathrm{C}_{3} \mathrm{~N}_{4}\right)$ gave a phenol yield of $18 \%$ with $95.9 \%$ phenol selectivity. The catalytic activity of $\mathrm{V} / m p-\mathrm{C}_{3} \mathrm{~N}_{4}$ is attributed to the high benzene-activation capability of $m p-\mathrm{C}_{3} \mathrm{~N}_{4}$ and dispersion of $\mathrm{V}$ species [12]. A $21 \%$ benzene conversion and $94 \%$ phenol selectivity were obtained over $\mathrm{CuO} / \mathrm{MCM}-41$ in the hydroxylation of benzene to phenol with $\mathrm{H}_{2} \mathrm{O}_{2}$ as the oxidant [13]. Kharat et al. [14] used Keggin-type V-substituted molybdophosphoric acid supported on amine-functionalized SBA-15; they achieved $20 \%$ benzene conversion and a phenol selectivity of $95 \%$. In a similar study, vanadium oxides supported on mesoporous silica MCM-41 functionalized with 3-aminopropyltrimethoxysilane gave $58.6 \%$ benzene conversion and 18.5\% phenol selectivity [15].

In recent years, mesoporous silica materials have been successfully used as catalyst supports because of their large uniform pore sizes, large pore volumes, and high surface areas [16-18]. These materials have various structures; SBA-16 has three-dimensional connected channels (cage like) and a cubic structure. These characteristics lead to high mass transfer of reactants. Moreover, its small input of pores prevents metal particle aggregation [19]. A review of the literature on SBA-16-supported metal shows that its activity is appropriate for direct hydroxylation of benzene. Zhu et al. [20] investigated the catalytic hydroxylation of benzene to phenol over $\mathrm{VO}_{x} / \mathrm{SBA}-16$ prepared using an impregnation method; they achieved $13.8 \%$ benzene conversion and $97.5 \%$ selectivity for phenol. More recently, Co-doped SBA-16, prepared using an evaporation-induced self-assembly method, gave a phenol yield of $28.8 \%$ and a phenol selectivity of $96.6 \%$ [21]. Cr compounds have also been used for benzene hydroxylation to phenol because of their high initial activities. However, only a few studies in which supported $\mathrm{Cr}$ was used as the active catalyst in this reaction have been reported; for example, $\mathrm{Cr}$ incorporated into an SAPO-37 framework, and $\mathrm{H}_{2} \mathrm{O}_{2}$ as the oxidant, gave a benzene conversion of $6 \%$ in acetonitrile at $353 \mathrm{~K}$ [22]. A phenol yield of $10.3 \%$ and a phenol selectivity of $98.4 \%$ were obtained over Cr-substituted large-pore zeolite- $\beta$ [23]. Tagawa et al. [24] investigated the catalytic hydroxylation of benzene to phenol over $\mathrm{K}_{2} \mathrm{Cr}_{2} \mathrm{O}_{7}$ supported on $\mathrm{SiO}_{2}$, using $\mathrm{H}_{2} \mathrm{O}_{2}$ as the oxidant; $1.4 \%$ benzene conversion was obtained in acetonitrile at room temperature. In another study, Pinnavaia et al. [25] prepared a Cr-substituted MCM-41 catalyst for the hydroxylation of benzene to phenol, and obtained approximately $100 \%$ phenol selectivity.

Although some catalysts with adequate performance have been reported, from the industrial perspective, it is essential to explore and prepare new catalysts with high selectivities that can be prepared using simple methods. Benzene oxidation to phenol is a competitive process, because phenol is more active toward oxidation than benzene is, therefore achieving high phenol selectivity without any by-products is still a challenge.

In addition to developing suitable catalyst preparation processes, optimization of the operating variables plays a key role in achieving a good catalytic performance. The published literature shows that parameters such as the amount of $\mathrm{H}_{2} \mathrm{O}_{2}$, reaction temperature, reaction time, and catalyst dosage have significant effects on the catalytic performance. Previous studies were performed using traditional one-factor-at-a-time approaches to optimize the operating parameters for good catalytic activity [26-31]. Such experimental methods are time consuming and costly, especially if a large number of operating variables need to be considered simultaneously. These methods do not consider interactions among the process variables and result in poor optimum conditions. Statistical techniques such as response surface methodology (RSM), which is a more accurate method, can be used for optimization of a fixed process. RSM is a mixture of mathematical and statistical techniques and can evaluate the effects of process variables and their interactions on response variables [32-34]. We used RSM to statistically optimize the operating parameters in benzene hydroxylation using a minimum number of experiments. To the best of our knowledge, no previous study aimed at the optimization of benzene hydroxylation using RSM has been conducted. Central composite design (CCD) is the most commonly used method for the RSM technique.

In the present study, a Cr/SBA-16 catalyst was synthesized using a simple impregnation method and tested in the hydroxylation of benzene to phenol. X-ray diffraction (XRD), ultraviolet-visible (UV-vis) spectroscopy, transmission electron microscopy (TEM), and the Brunauer-Emmett-Teller (BET) method were used for catalyst characterization. The effects of four operating factors, namely the amount of $\mathrm{H}_{2} \mathrm{O}_{2}$, reaction temperature, reaction time, and catalyst dosage, and their interactions, on the catalytic performance were investigated using CCD coupled with RSM. The yield and phenol selectivity under the optimized conditions were determined. The results showed that $\mathrm{Cr}$ supported on mesoporous silica is an effective catalyst for the direct hydroxylation of benzene to phenol using $\mathrm{H}_{2} \mathrm{O}_{2}$ as the oxidant.

\section{Experimental}

\subsection{Catalyst preparation}

Pluronic F127 ( $\left.\mathrm{EO}_{106} \mathrm{PO}_{70} \mathrm{EO}_{106}, M_{\mathrm{w}}=13600\right)$, sodium silicate solution $\left(\mathrm{SiO}_{2} 26 \%, \mathrm{Na}_{2} \mathrm{O} \%\right.$ ) as a silica source, $\mathrm{HNO}_{3}$ (65\%), $\mathrm{Cr}\left(\mathrm{NO}_{3}\right)_{3} \cdot 9 \mathrm{H}_{2} \mathrm{O}$, acetonitrile, benzene, $\mathrm{H}_{2} \mathrm{O}_{2}$ (30\%), and toluene were purchased from the Merck Company.

Mesoporous silica SBA-16 with minor modifications was prepared using the method described in the literature [35]. Pluronic F127 (14.1 g) was dissolved in $\mathrm{HNO}_{3}$ (65\%, $144 \mathrm{~mL}$ ) and deionized water $(900 \mathrm{~mL})$. The solution was stirred at 303 $\mathrm{K}$. Sodium silicate solution ( $62.4 \mathrm{~g}$ ) was added and the reaction mixture was stirred at $300 \mathrm{r} / \mathrm{min}$ for $3 \mathrm{~h}$ at $343 \mathrm{~K}$. The product was kept at $373 \mathrm{~K}$ for $24 \mathrm{~h}$. The surfactant was extracted using ethanol and $\mathrm{HCl}(2 \mathrm{~mol} / \mathrm{L})$, and the obtained solid was calcined at $823 \mathrm{~K}$ for $5 \mathrm{~h}$.

The catalyst was prepared via an impregnation method as follows. SBA-16 (1 g) was dipped in a solution obtained by dissolving $\mathrm{Cr}\left(\mathrm{NO}_{3}\right)_{3} \cdot 9 \mathrm{H}_{2} \mathrm{O}(0.92 \mathrm{~g})$ in water $(50 \mathrm{~mL})$. The solvent 
was evaporated at $313 \mathrm{~K}$ while the reaction mixture was stirred vigorously. The obtained sample was dried at $353 \mathrm{~K}$ for $8 \mathrm{~h}$ and calcined at $823 \mathrm{~K}$ for $5 \mathrm{~h}$. The collected powder was denoted by $\mathrm{Cr} / \mathrm{SBA}-16$; the metal content of the catalyst (determined using inductively coupled plasma atomic emission spectroscopy) was $2.2 \mathrm{mmol} / \mathrm{g}$.

\subsection{Catalyst characterization}

$\mathrm{N}_{2}$ adsorption-desorption isotherms were obtained using a BELSORP-mini II instrument at $77 \mathrm{~K}$. The BET equation was used to calculate specific surface areas and the BJH equation was used to determine the pore size distributions and total pore volumes. Powder XRD measurements were performed using $\mathrm{Cu} K_{\alpha}$ radiation (X'Pert-PRO X-ray diffractometer). TEM images were obtained using a Philips EM-208 instrument at $100 \mathrm{kV}$. UV-vis spectra were obtained using a Rayleigh UV-1600 spectrophotometer. The UV-vis absorption spectrum of a solid sample was obtained by addition of a known sample to spectral grade $n$-decane; a quartz window with a path length of $0.5 \mathrm{~mm}$ was used. The solid sample had very low light scattering in $n$-decane. A reasonable-quality spectrum was obtained, because the reflective index of $n$-decane is very close to that of silica SBA-16.

\section{3. $\mathrm{Cr} / \mathrm{SBA}-16$ catalytic activity tests}

$\mathrm{Cr} / \mathrm{SBA}-16$ was used in the direct hydroxylation of benzene to phenol with $\mathrm{H}_{2} \mathrm{O}_{2}$ as the oxidant. The reaction was performed in a $50 \mathrm{~mL}$ round-bottomed flask equipped with a reflux condenser and a magnetic stirrer. The desired amount of catalyst $(0.06-0.12 \mathrm{~g})$ was immersed in acetonitrile $(6 \mathrm{~mL}, 114$ mmol), and other parameters such as the amount of $30 \% \mathrm{H}_{2} \mathrm{O}_{2}$ aq. (2-4 mL), reaction temperature (308-358 K), and reaction time (4-8 h) were adjusted according to experiments designed using Design Expert 7.1.3 Software. The mixture was heated to the desired reaction temperature, and benzene $(1 \mathrm{~mL}, 11.26$ mmol) was added. The reaction mixture was cooled, the catalyst was separated by centrifugation, and a small amount of ethanol was added to the liquid product, resulting in formation of a single-phase liquid for gas chromatography (GC) analysis.

The liquid products were analyzed using a GC instrument (Perkin-Elmer 8500) equipped with a flame ionization detector. Quantitative analysis of the liquid products was performed based on calibration curves, with toluene as an internal standard. 1,4-Benzoquinone was identified as a by-product in some experiments.

\subsection{Experimental design}

RSM is an affordable and reliable method for optimizing certain processes. This technique reduces the number of designed experiments needed to investigate the effects of operating factors. In general, a second-order polynomial model is used in RSM analysis (Eq. (1)):

$$
Y=\beta_{0}+\sum_{i=1}^{k} \beta_{i} x_{i}+\sum_{i=1}^{k} \beta_{i i} x_{i}^{2}+\sum_{i<j} \beta_{i j} x_{i} x_{j}+e
$$

where $Y$ is the predicted response, $\beta_{0}$ is the intercept term, $\beta_{\mathrm{i}}$ is the linear factor coefficient, $x_{i}$ is the variable attributed to factor $i, x_{j}$ is the variable attributed to factor $j, \beta_{i j}$ is the interaction factor coefficient, $\beta_{i i}$ is the quadratic factor coefficient, $k$ is the number of factors, and $e$ is the random error [36].

Design Expert Software (version 7.1.3) was used for experimental design and analysis of the obtained results. CCD is an experimental design that includes a two-level factorial design with center points, and is completed with a set of axial (or star) points to assess the curvature. In this work, CCD coupled with RSM was used to investigate the effects of various operating factors, namely reaction temperature, $\mathrm{H}_{2} \mathrm{O}_{2}$ content, and catalyst dosage, on benzene hydroxylation over a Cr/SBA-16 catalyst. The phenol yield was considered as a response variable. Overall, the experimental design involved 30 experiments, in the following sections: (I) 16 runs using the two-level factorial design, (II) one center point and its five repeats to determine the curvature and pure errors (caused by replicating experiments), and (III) eight runs for axial points (shown as $-\alpha$ and $+\alpha$ ). The actual and coded levels of the independent factors are shown in Table 1.

\section{Results and discussion}

\subsection{Catalyst characterization}

The low-angle XRD patterns of SBA-16 and Cr/SBA-16 are shown in Fig. 1(a). Both patterns had one sharp reflection at $2 \theta$ $\approx 0.74^{\circ}$ and one minor peak at $2 \theta \approx 1.3^{\circ}$; these are indexed to (110) and (211) reflections and correspond to the SBA-16 cubic structure with the $\operatorname{Im} \overline{3} \mathrm{~m}$ space group. The peak intensities for SBA-16 decreased after Cr loading, possibly because of incorporation of a large amount of $\mathrm{Cr}$ species into the support pores. Wide-angle XRD analysis of $\mathrm{Cr} / \mathrm{SBA}-16$ with a high $\mathrm{Cr}$ loading showed that the strong diffraction peaks were related to the $\mathrm{Cr}_{2} \mathrm{O}_{3}$ phase (Fig. 1(b)) [37].

The $\mathrm{N}_{2}$ adsorption-desorption isotherms and pore size distributions of SBA-16 and Cr/SBA-16 are shown in Fig. 2. Both samples showed type IV isotherms with $\mathrm{H} 2$ hysteresis loops in the range $p / p_{0}=0.4-0.75$; these are indicative of cage-like structures, i.e., the ordered mesoporous structure of the support was retained during catalyst preparation and did not collapse. A decrease in the pore volume could be caused by the presence of $\mathrm{Cr}$ species inside the support pores. The textural characteristics of the samples are summarized in Table 2. The surface area, total pore volume, and pore diameter decreased after $\mathrm{Cr}$ loading; this shows that $\mathrm{Cr}$ particles were introduced into the internal surfaces of SBA-16.

TEM was used for further investigation of the structural properties of the prepared samples (Fig. 3). Fig. 3(a) clearly

Table 1

Actual and coded levels of independent factors.

\begin{tabular}{lccccc}
\hline \multirow{2}{*}{ Independent factor } & \multicolumn{5}{c}{ Level } \\
\cline { 2 - 6 } & $-\alpha(-2)$ & -1 & 0 & +1 & $+\alpha(+2)$ \\
\hline A: Reaction temperature (K) & 283 & 308 & 333 & 358 & 383 \\
$B$ : Reaction time (h) & 2 & 4 & 6 & 8 & 10 \\
C: Amount of $\mathrm{H}_{2} \mathrm{O}_{2}(\mathrm{~mL})$ & 1 & 2 & 3 & 4 & 5 \\
$D$ : Catalyst dosage $(\mathrm{g})$ & 0.03 & 0.06 & 0.09 & 0.12 & 0.15 \\
\hline
\end{tabular}



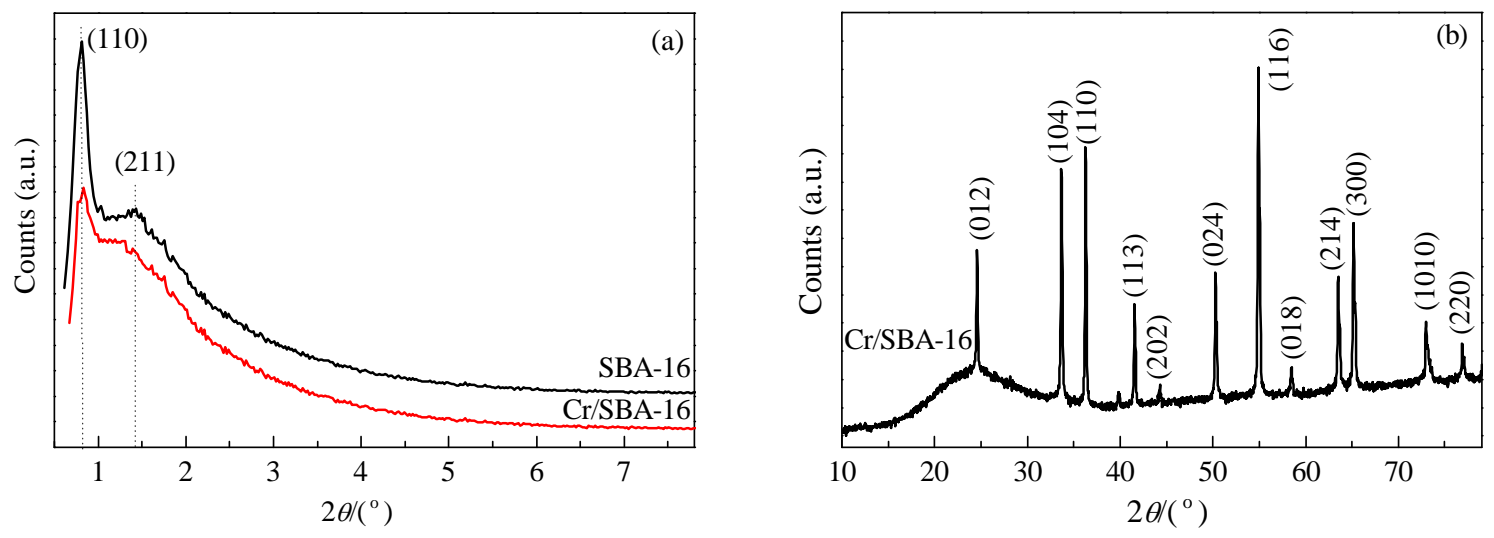

Fig. 1. Low-angle XRD patterns of SBA-16 and Cr/SBA-16 (a) and wide-angle XRD pattern of Cr/SBA-16 (b).

shows that SBA-16 has a well-ordered mesostructure. The TEM image of the Cr/SBA-16 catalyst (Fig. 3(b)) shows that the mesoporous structure of the support was retained after impregnation with chromium nitrate. The XRD patterns, $\mathrm{N}_{2}$ adsorption-desorption isotherms, and TEM images confirm that the structure of the synthesized catalyst did not collapse during its preparation.

The coordination geometry of $\mathrm{Cr}$ depends strongly on the support type and composition, metal loading, heat treatment, and support surface chemistry. UV-vis spectroscopy was used for further investigation of the coordination of chromium oxides in the Cr/SBA-16 catalyst; the spectrum is shown in Fig. 4. The two bands at 265 and $351 \mathrm{~nm}$ can be attributed to O-Cr(VI) charge transfer of chromium oxides, which are present in the form of monochromate. A central $\mathrm{Cr}(\mathrm{VI})$ ion could react with two silanol groups on the support surface. The weak broad band at around $440 \mathrm{~nm}$ can be assigned to $\mathrm{Cr}_{2} \mathrm{O}_{3}$ crystals,

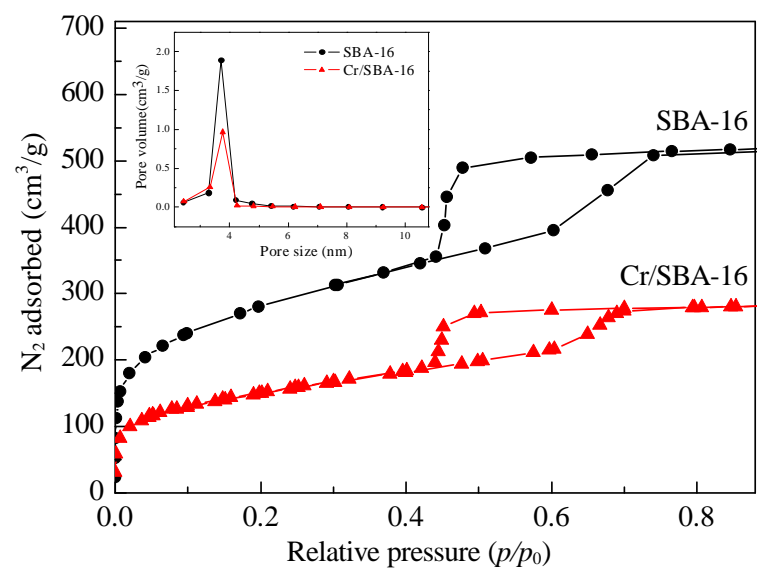

Fig. 2. $\mathrm{N}_{2}$ adsorption-desorption isotherms and pore size distributions (inset) of SBA-16 and Cr/SBA-16.

Table 2

Porosimetry results for SBA- 16 and $10.2 \mathrm{wt} \% \mathrm{Cr} / \mathrm{SBA}-16$.

\begin{tabular}{lccc}
\hline Sample & $\begin{array}{c}\text { BET surface } \\
\text { area }\left(\mathrm{m}^{2} / \mathrm{g}\right)\end{array}$ & $\begin{array}{c}\text { Pore } \\
\text { diameter }\end{array}(\mathrm{nm})$ & $\begin{array}{c}\text { Total pore } \\
\text { volume }\left(\mathrm{cm}^{3} / \mathrm{g}\right)\end{array}$ \\
\hline SBA-16 & 964 & 3.7 & 0.819 \\
$10.2 \mathrm{wt} \% \mathrm{Cr} / \mathrm{SBA}-16$ & 542 & 3.6 & 0.444 \\
\hline
\end{tabular}

${ }^{a}$ Calculated from the desorption branch. as suggested by the XRD result, or to dichromate, in which a central $\mathrm{Cr}(\mathrm{VI})$ ion could react with only one silanol group (Scheme 1) [38].

\subsection{Optimization of operating variables}

\subsubsection{Model results}

A second-order polynomial model for phenol yield was obtained using Design Expert 7.1.3 Software; the experimental results are shown in Table 3. The final regression model, based on the coded values for phenol yield, is shown in Eq. (2). In this model, $Y$ (phenol yield) is expressed as a function of $A$ (reaction temperature), $B$ (reaction time), $C$ (amount of $\mathrm{H}_{2} \mathrm{O}_{2}$ ), and $D$ (catalyst dosage).
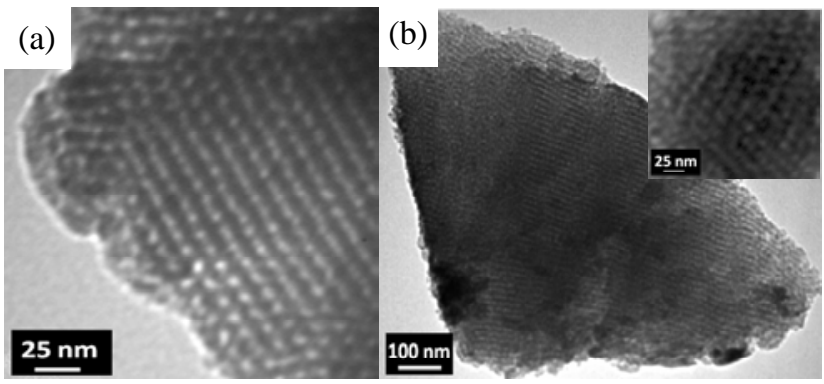

Fig. 3. TEM images of SBA-16 support (a) and Cr/SBA-16 (b).

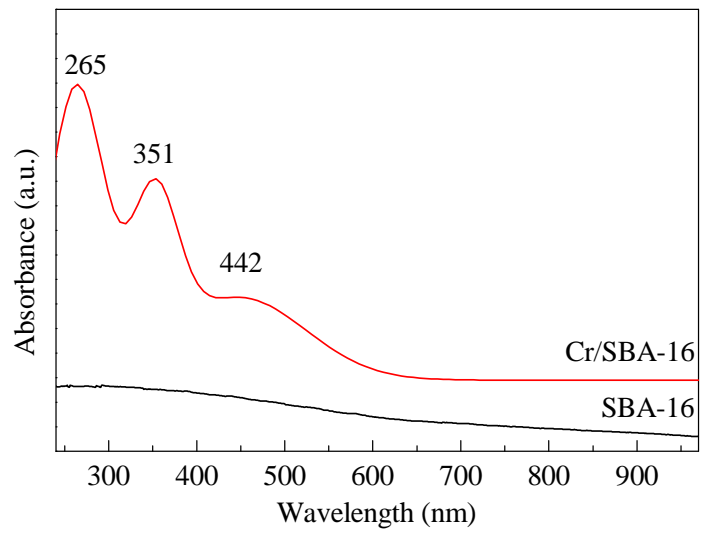

Fig. 4. UV-vis spectra of SBA-16 and Cr/SBA-16. 


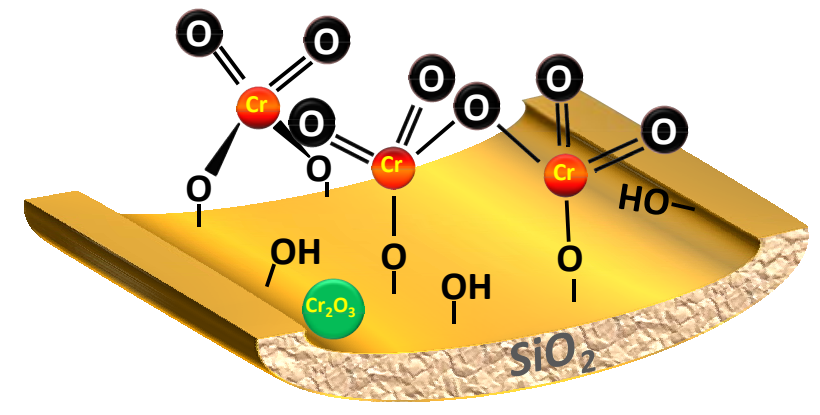

Scheme 1. Coordination geometry of chromium on support.

$$
\begin{gathered}
\text { Phenol yield }=9.46+0.35 A+0.41 B+0.6 C+1.13 D-1.24 A B \\
-0.34 A C+0.79 A D+0.64 B C-0.51 B D+0.38 C D \\
-1.56 A^{2}-0.11 B^{2}-1.69 C^{2}-1.48 D^{2}
\end{gathered}
$$

Eq. (2) was used to predict the phenol yield over the prepared catalyst with various operating parameters within the selected experimental ranges. The competence of the model was assessed using analysis of variance (ANOVA) and the Fish-

\begin{tabular}{|c|c|c|c|c|c|c|c|c|}
\hline \multirow{2}{*}{ Run } & \multirow{2}{*}{$\begin{array}{l}\text { Molar } \\
\text { ratio }^{\mathrm{a}}\end{array}$} & \multirow{2}{*}{ Block } & \multirow{2}{*}{$\begin{array}{c}A \\
(\mathrm{~K})\end{array}$} & \multirow{2}{*}{$\begin{array}{c}B \\
(\mathrm{~h})\end{array}$} & \multirow{2}{*}{$\begin{array}{c}C \\
(\mathrm{~mL})\end{array}$} & \multirow{2}{*}{$\begin{array}{c}D \\
(\mathrm{~g})\end{array}$} & \multicolumn{2}{|c|}{ Phenol yield (\%) } \\
\hline & & & & & & & Observed $\mathrm{b}$ & Predicted \\
\hline 1 & $1: 10.2: 1.7$ & 1 & 308 & 4 & 2 & 0.12 & 3.20 & 3.07 \\
\hline 2 & $1: 10.2: 3.5$ & 1 & 358 & 4 & 4 & 0.06 & 2.25 & 2.88 \\
\hline 3 & $1: 10.2: 1.7$ & 1 & 358 & 8 & 2 & 0.12 & 4.13 & 4.54 \\
\hline 4 & 1:10.2:3.5 & 1 & 308 & 4 & 4 & 0.12 & 4.11 & 4.43 \\
\hline 5 & $1: 10.2: 1.7$ & 1 & 308 & 4 & 2 & 0.06 & 1.92 & 2.14 \\
\hline 6 & 1:10.2:3.5 & 1 & 308 & 4 & 4 & 0.06 & 2.39 & 1.97 \\
\hline 7 & 1:10.2:1.7 & 1 & 308 & 8 & 2 & 0.06 & 4.51 & 5.19 \\
\hline 8 & $1: 10.2: 2.7$ & 1 & 333 & 6 & 3 & 0.09 & 10.28 & 9.74 \\
\hline 9 & 1:10.2:3.5 & 1 & 358 & 4 & 4 & 0.12 & 9.19 & 9.06 \\
\hline 10 & 1:10.2:2.7 & 1 & 333 & 6 & 3 & 0.09 & 9.82 & 8.51 \\
\hline 11 & 1:10.2:1.7 & 1 & 308 & 8 & 2 & 0.12 & 4.60 & 4.08 \\
\hline 12 & 1:10.2:1.7 & 1 & 358 & 8 & 2 & 0.06 & 2.72 & 2.50 \\
\hline 13 & 1:10.2:1.7 & 1 & 358 & 4 & 2 & 0.12 & 8.38 & 8.49 \\
\hline 14 & 1:10.2:3.5 & 1 & 308 & 8 & 4 & 0.12 & 8.31 & 8.00 \\
\hline 15 & $1: 10.2: 2.7$ & 1 & 333 & 6 & 3 & 0.09 & 9.72 & 9.74 \\
\hline 16 & 1:10.2:3.5 & 1 & 358 & 8 & 4 & 0.06 & 3.42 & 3.54 \\
\hline 17 & 1:10.2:2.7 & 1 & 333 & 6 & 3 & 0.09 & 9.42 & 9.74 \\
\hline 18 & 1:10.2:1.7 & 1 & 358 & 4 & 2 & 0.06 & 4.10 & 4.40 \\
\hline 19 & 1:10.2:3.5 & 1 & 308 & 8 & 4 & 0.06 & 7.58 & 7.57 \\
\hline 20 & 1:10.2:3.5 & 1 & 358 & 8 & 4 & 0.12 & 7.23 & 7.12 \\
\hline 21 & 1:10.2:2.7 & 2 & 383 & 6 & 3 & 0.09 & 3.83 & 3.62 \\
\hline 22 & 1:10.2:2.7 & 2 & 333 & 6 & 3 & 0.09 & 8.72 & 9.18 \\
\hline 23 & $1: 10.2: 2.7$ & 2 & 283 & 6 & 3 & 0.09 & 2.09 & 2.24 \\
\hline 24 & 1:10.2:2.7 & 2 & 333 & 10 & 3 & 0.09 & 9.52 & 9.57 \\
\hline 25 & 1:10.2:2.7 & 2 & 333 & 6 & 3 & 0.15 & 5.01 & 5.53 \\
\hline 26 & 1:10.2:2.7 & 2 & 333 & 6 & 3 & 0.09 & 9.34 & 9.18 \\
\hline 27 & 1:10.2:4.4 & 2 & 333 & 6 & 5 & 0.09 & 3.34 & 3.63 \\
\hline 28 & 1:10.2:2.7 & 2 & 333 & 6 & 3 & 0.03 & 1.60 & 1.02 \\
\hline 29 & 1.1:11.5:1 & 2 & 333 & 6 & 1 & 0.09 & 1.58 & 1.23 \\
\hline 30 & $1: 10.2: 2.7$ & 2 & 333 & 2 & 3 & 0.09 & 8.03 & 7.91 \\
\hline
\end{tabular}

Table 3

Design experiment matrix based on CCD.

Reaction conditions: benzene $(1 \mathrm{~mL}, 11.26 \mathrm{mmol})$, acetonitrile $(6 \mathrm{~mL}$ $114.8 \mathrm{mmol})$.

a Benzene:acetonitrile: $\mathrm{H}_{2} \mathrm{O}_{2}$ molar ratio.

${ }^{\mathrm{b}}$ Phenol yield $=\mathrm{mmol}$ product $/ \mathrm{mmol}$ initial benzene.
Table 4

ANOVA results for response variables.

\begin{tabular}{lrcrcc}
\hline Source & $\begin{array}{r}\text { Sum of } \\
\text { squares }\end{array}$ & $\begin{array}{c}\text { Degree of } \\
\text { freedom }\end{array}$ & $\begin{array}{c}\text { Mean } \\
\text { square }\end{array}$ & $F$-value & $\begin{array}{c}P \text {-value } \\
\text { (probability }>F \text { ) }\end{array}$ \\
\hline Block & 2.07 & 1 & 2.07 & - & - \\
Model & 260.30 & 14 & 18.59 & 66.34 & $<0.0001^{\mathrm{a}}$ \\
Residual & 3.92 & 14 & 0.28 & - & - \\
Lack of fit & 3.35 & 10 & 0.34 & 2.35 & $0.2124 \mathrm{~b}$ \\
Pure error & 0.57 & 4 & 0.14 & - & - \\
Total & 266.30 & 29 & - & - & - \\
\hline$R^{2}=0.985$, adjusted $R^{2}=0.970$, predicted $R^{2}=0.912$, adequate precision \\
$=$ 22.56. \\
a Significant. b Not significant.
\end{tabular}

er test (F-test), with a 95\% confidence level. The statistical terms obtained from ANOVA are listed in Table 4.

The ANOVA results (Table 4) show that this model can be used in the considered design space. The $F$-value of 66.34 for the phenol yield implies that the model is significant, i.e., there is only a $0.01 \%$ chance $(P<0.0001)$ that the model results could arise from noise. The lack-of-fit term is the variation in the data around the fitted model. If a fixed model does not fit the data well, this will be significant. Here, the $P$-value of the lack of fit was more than 0.05 , implying that the selected model was based on statistical logic ( $P$ greater than 0.05 is desirable). The correlation coefficient is often used to determine the goodness of fit between model and experimental data. A reasonable statistical model should have a correlation coefficient close to unity. The high coefficient of determination $\left(R^{2}=\right.$ 0.985 ) indicates that there is good agreement between the experimental and predicted phenol yields. The desirable value of adequate precision (signal-to-noise ratio) is greater than 4 . Here, a ratio of 22.56 was obtained for $Y$, implying that this model can be used to navigate the design space.

The regression plot of predicted values versus actual values for phenol yield is shown in Fig. 5. It shows that the values predicted using Eq. (2) were close to the experimental ones, indicating that the proposed model is credible for expressing the correlation between the effective parameters and the phenol yield. A normal data distribution is shown by the normal probability plot (Fig. 6). It can be seen that the data were normally distributed, because the data were sorted close to a straight line.

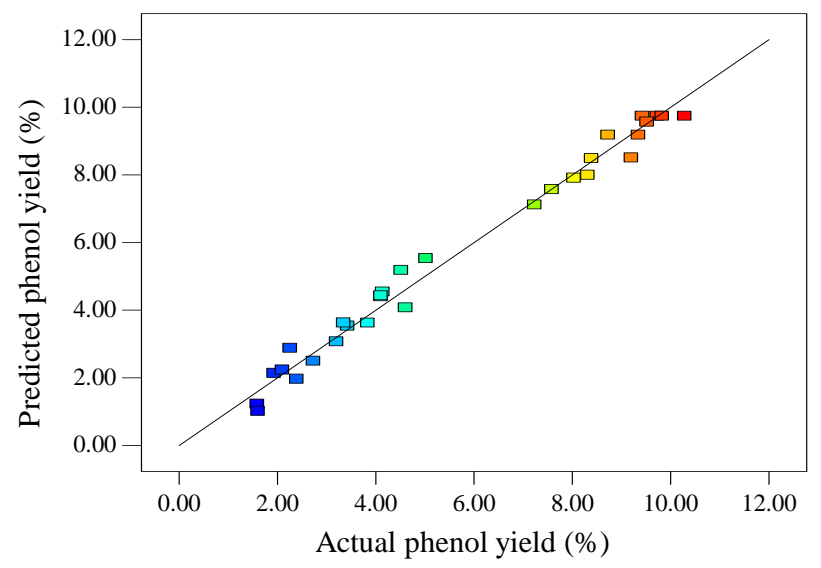

Fig. 5. Plot of actual vs predicted values of phenol yield. 


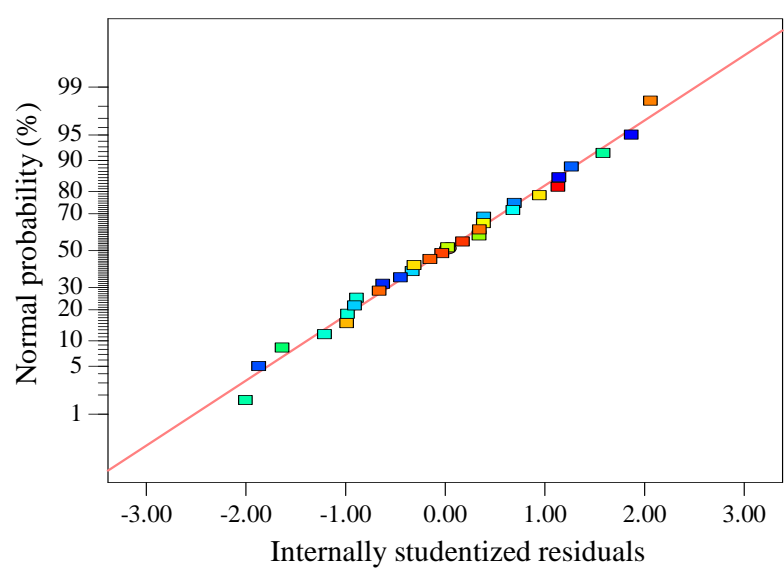

Fig. 6. Normal probability plot of residuals.

\subsubsection{Effects of reaction temperature and reaction time on phenol yield}

Three-dimensional response surface plots were used to investigate the effects of the operating variables and their interactions on the phenol yield. These curves show the simultaneous effects of two parameters on a response variable, while the other factors remain at the center point in the design space. Fig. 7 (a) shows the effects of reaction time and temperature on the phenol yield, with two other variables kept at the center point in the design space (the amount of $\mathrm{H}_{2} \mathrm{O}_{2}$ and catalyst dosage are $3 \mathrm{~mL}$ and $0.09 \mathrm{~g}$, respectively). Initially, increasing the reaction
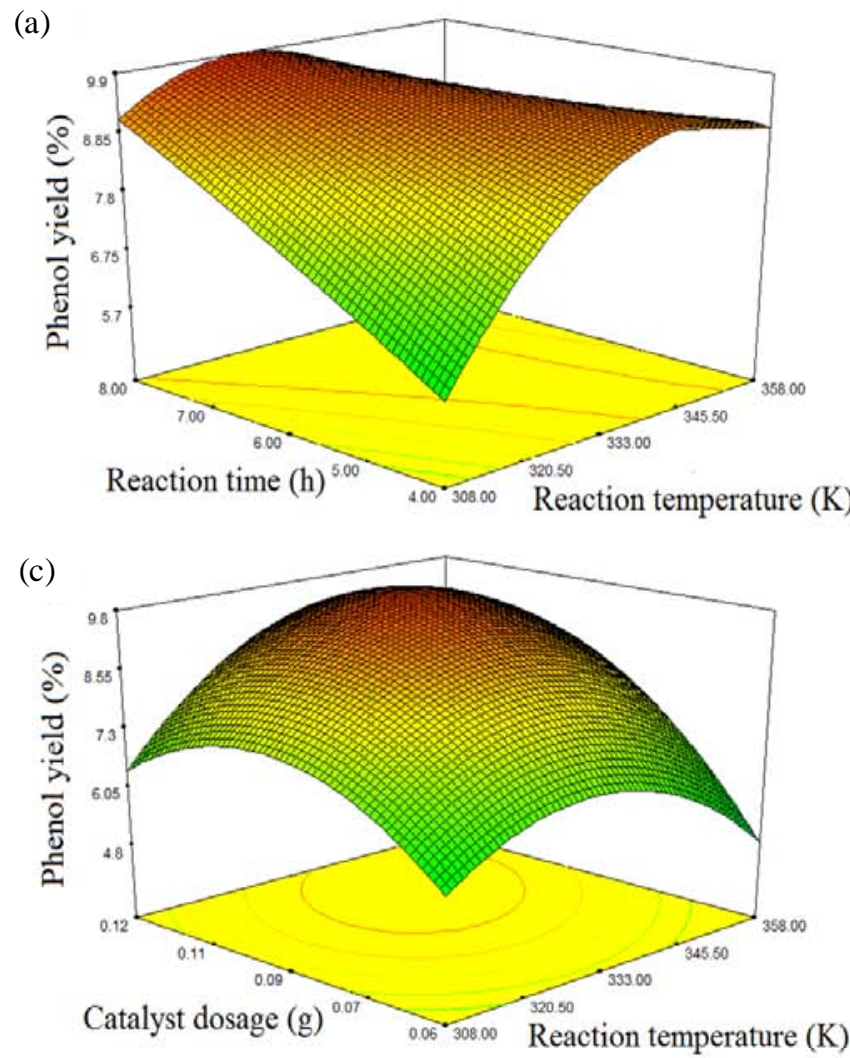

temperature and time (around $333 \mathrm{~K}$ and $7.5 \mathrm{~h}$ ) improves the catalytic performance, resulting in an increased phenol yield. This may be the result of $\mathrm{H}_{2} \mathrm{O}_{2}$ decomposition to active species with increasing temperature. Fig. 7(a) also shows that further increasing the reaction temperature leads to a decline in the phenol yield; this can be attributed to self-decomposition of $\mathrm{H}_{2} \mathrm{O}_{2}$ to water at high temperature [39].

\subsubsection{Effects of reaction temperature and amount of $\mathrm{H}_{2} \mathrm{O}_{2}$ on phenol yield}

The combined effects of the amount of $\mathrm{H}_{2} \mathrm{O}_{2}$ and reaction temperature on the phenol yield are shown in Fig. 7(b). The phenol yield increased greatly when the amount of $\mathrm{H}_{2} \mathrm{O}_{2}$ and the temperature were increased to $3 \mathrm{~mL}$ and $333 \mathrm{~K}$, respectively. This may be the result of an increasing number of active species on the catalyst surface. The figure also shows that further increasing the amount of $\mathrm{H}_{2} \mathrm{O}_{2}$ and the reaction temperature results in a decrease in the phenol yield. This decrease can be attributed to over-oxidation of phenol to 1,4-benzoquinone, which was identified by GC. A high phenol yield was therefore achieved at the zero coded level of reaction temperature and amount of $\mathrm{H}_{2} \mathrm{O}_{2}$ under these conditions.

\subsubsection{Effects of reaction temperature and catalyst dosage on phenol yield}

Fig. 7(c) shows the combined effects of reaction temperature and catalyst dosage on the phenol yield. The phenol yield
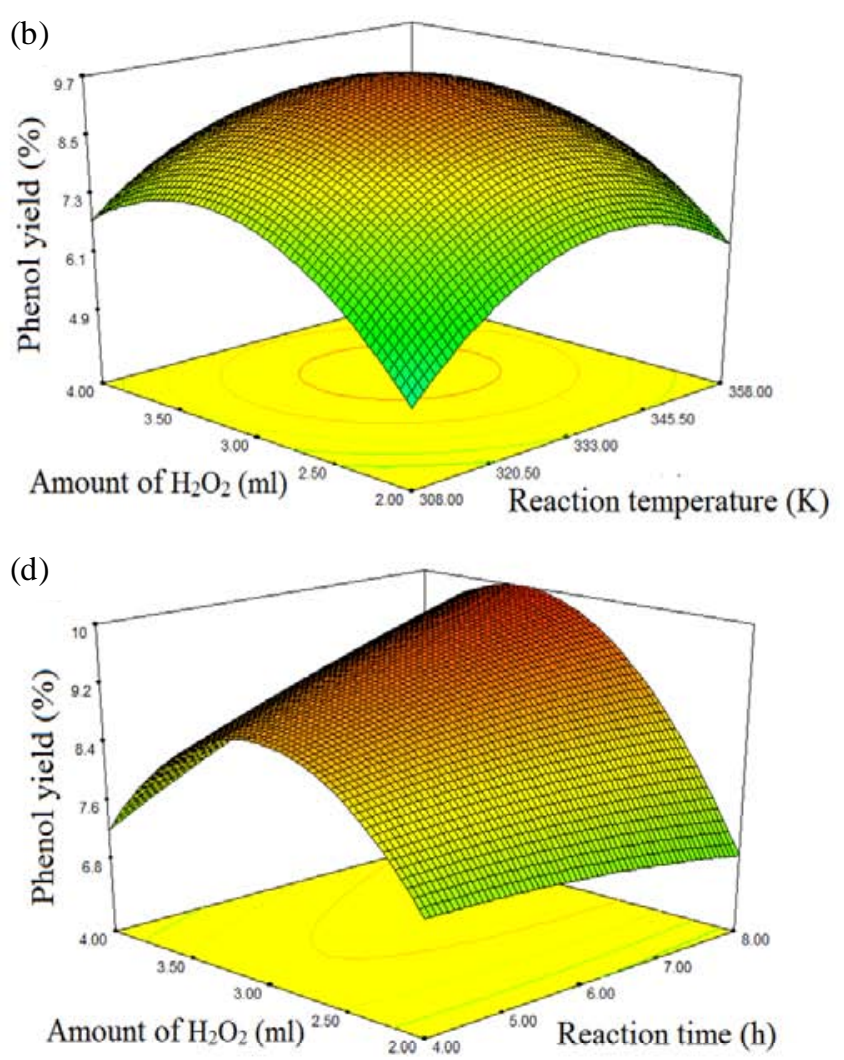

Fig. 7. Response surface plots for effects of process variables on phenol yield. (a) Reaction temperature and reaction time; (b) Reaction temperature and amount of $\mathrm{H}_{2} \mathrm{O}_{2}$; (c) Reaction temperature and catalyst dosage; (d) Amount of $\mathrm{H}_{2} \mathrm{O}_{2}$ and reaction time. 
increased when the reaction temperature and catalyst dosage were increased to $333 \mathrm{~K}$ and $0.09 \mathrm{~g}$, respectively. This could be the result of increasing numbers of available catalytic sites on the Cr/SBA-16 surface. However, the phenol yield decreased with further increases in the reaction temperature and catalyst dosage. This may be caused by phenol conversion to 1,4-benzoquinone, which was confirmed by GC.

\subsubsection{Effects of amount of $\mathrm{H}_{2} \mathrm{O}_{2}$ and reaction time on phenol yield}

The effects of the amount of $\mathrm{H}_{2} \mathrm{O}_{2}$ and reaction time on the phenol yield are shown in Fig. $7(\mathrm{~d})$; the reaction temperature and catalyst dosage were $333 \mathrm{~K}$ and $0.09 \mathrm{~g}$, respectively. Fig. 7 (d) shows that the reaction time did not greatly affect the phenol yield when the $\mathrm{H}_{2} \mathrm{O}_{2}$ content was around $3 \mathrm{~mL}$. The phenol yield increased up to $3 \mathrm{~mL}$ and then decreased; the reaction time had little effect on the phenol yield.

\subsubsection{Effects of catalyst dosage and reaction time on phenol yield}

Fig. 8(a) shows the effects of the catalyst dosage and reaction time on the catalytic activity of $\mathrm{Cr} / \mathrm{SBA}-16$, while the two other factors were kept at the zero coded level (the amount of $\mathrm{H}_{2} \mathrm{O}_{2} 3 \mathrm{~mL}$ and reaction temperature $333 \mathrm{~K}$ ). It was observed that with increasing catalyst dosage to around $0.95 \mathrm{~g}$, the phenol yield increased, whereas the reaction time did not greatly affect the phenol yield.

\subsubsection{Effects of amount of $\mathrm{H}_{2} \mathrm{O}_{2}$ and catalyst dosage on phenol yield}

The effects of the amount of $\mathrm{H}_{2} \mathrm{O}_{2}$ and catalyst dosage on the phenol yield are shown in Fig. 8(b) (the reaction time $6 \mathrm{~h}$ and the reaction temperature $333 \mathrm{~K}$ ). It can be deduced that both parameters considerably affected the phenol yield. The maximum phenol yield was achieved when the amount of $\mathrm{H}_{2} \mathrm{O}_{2}$ and catalyst dosage were near the central points.

\subsubsection{Optimization of phenol yield and validation of proposed model}

Design Expert 7.1.3 software was used to determine the optimum conditions for direct hydroxylation of benzene to phenol. The phenol yield was defined as a maximum in the design space. An experiment was performed under the predicted optimum conditions to verify the model. The phenol yield predicted by the proposed model was $10.16 \%$, whereas the phenol yield obtained experimentally was $9.05 \%$. These results show that there is good agreement between the RSM second-order polynomial model and the experimental data (Table 5). Under the optimum conditions, the prepared catalyst gave a high performance, especially in terms of phenol selectivity.

\subsection{Comparison of activities of prepared catalyst and various reported catalysts}

The catalytic efficiency of the prepared catalyst was compared with those of some Cr-based catalysts on other types of support in the direct hydroxylation of benzene. The data in Table 6 show that the Cr/SBA-16 catalyst gave a higher selectivity for, and yield of, phenol compared with other Cr-based catalysts. It is worth noting that the catalytic performance of Cr-MCM-41 was achieved using a high temperature and time, whereas the $\mathrm{Cr} / \mathrm{SBA}-16$ showed high activity under mild reaction conditions. The good activity of this catalyst is suggested to be the result of a high surface area, large pore volume, and the
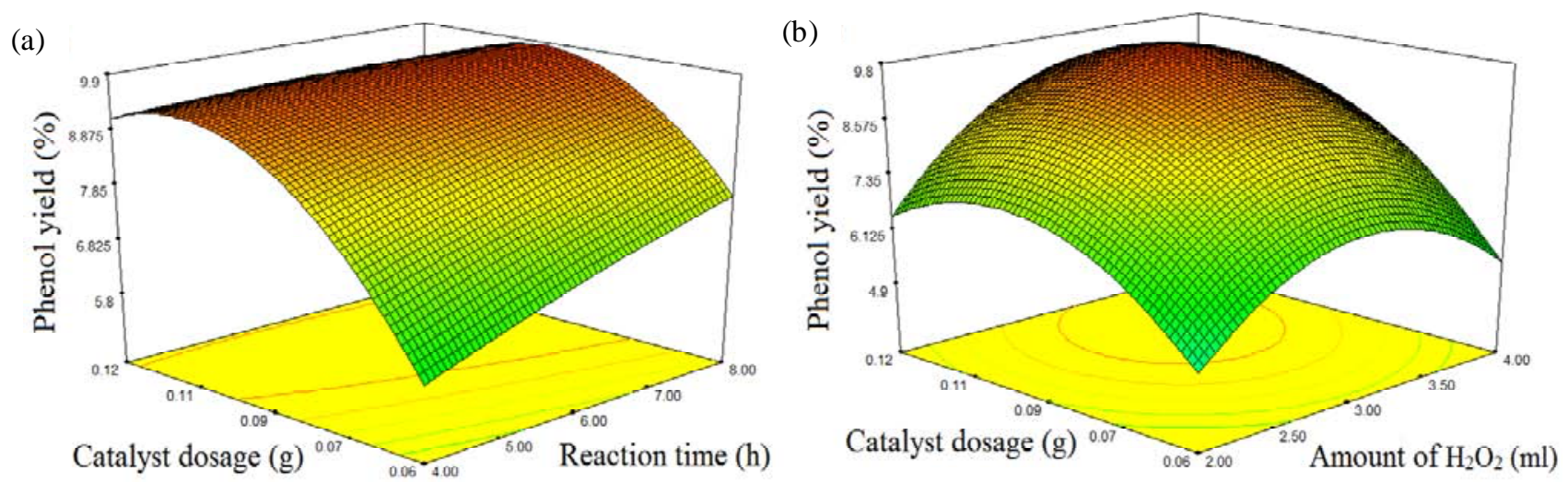

Fig. 8. Response surface plots for effects of process variables on phenol yield. (a) Catalyst dosage and reaction time; (b) Amount of $\mathrm{H}_{2} \mathrm{O}_{2}$ and catalyst dosage.

Table 5

Observed and predicted results for phenol yield under optimum points identified by RSMa .

\begin{tabular}{lccccccc}
\hline Molar ratio $^{\text {b }}$ & $\begin{array}{c}\text { Reaction } \\
\text { temperature }(\mathrm{K})\end{array}$ & $\begin{array}{c}\text { Reaction time } \\
(\mathrm{h})\end{array}$ & $\begin{array}{c}\text { Amount of } \mathrm{H}_{2} \mathrm{O}_{2} \\
(\mathrm{~mL})\end{array}$ & $\begin{array}{c}\text { Catalyst dosage } \\
(\mathrm{g})\end{array}$ & $\begin{array}{c}\text { Predicted phenol } \\
\text { yield (\%) }\end{array}$ & $\begin{array}{c}\text { Observed phenol } \\
\text { yield (\%) }\end{array}$ & $\begin{array}{c}\text { Observed phenol } \\
\text { selectivity }(\%)\end{array}$ \\
\hline $1: 10.2: 2.9$ & 324 & 8 & 3.28 & 0.09 & 10.16 & 9.05 & 100 \\
\hline
\end{tabular}

a Other conditions of benzene hydroxylation for all runs: benzene $(1 \mathrm{~mL}, 11.26 \mathrm{mmol})$, acetonitrile $(6 \mathrm{~mL}, 114.8 \mathrm{mmol})$.

b Benzene:acetonitrile: $\mathrm{H}_{2} \mathrm{O}_{2}$ molar ratio.

c Phenol selectivity $=\mathrm{mmol}$ phenol $/ \mathrm{mmol}$ product. 
Table 6

Comparison of catalytic performance of various $\mathrm{Cr}$-based catalysts for hydroxylation of benzene.

\begin{tabular}{lccccccc}
\hline Catalyst & Phenol selectivity (\%) & Phenol yield (\%) & Benzene conversion (\%) & $W_{\text {catalyst }}(\mathrm{mg})$ & $T(\mathrm{~K})$ & $t(\mathrm{~h})$ & Ref. \\
\hline $\mathrm{Na}^{+}-\mathrm{CrAPSO}-37$ a & $\approx 100$ & - & 6 & 20 & 373 & 24 & {$[22]$} \\
$\mathrm{CrAl}-\mathrm{\beta}-\mathrm{C}^{\mathrm{b}}$ & 98.4 & - & 10.3 & 200 & 328 & 6 & {$[24]$} \\
$\mathrm{K}_{2} \mathrm{Cr}_{2} \mathrm{O}_{7} / \mathrm{SiO}_{2}{ }^{\mathrm{c}}$ & - & 1.4 & - & 10000 & 293 & $\approx 2.67$ & {$[25]$} \\
$\mathrm{Cr}-\mathrm{MCM}-41{ }^{\mathrm{d}}$ & $\approx 100$ & - & N.A. e & 25 & 345 & 24 & {$[23]$} \\
$\mathrm{Cr} / \mathrm{SBA}-16$ & 100 & 9.05 & 9.05 & 90 & 324 & 8 & this work \\
\hline
\end{tabular}

a Benzene (5 mmol), $\mathrm{H}_{2} \mathrm{O}_{2}(5 \mathrm{mmol}, 30 \mathrm{wt} \%)$, acetonitrile ( $\left.3 \mathrm{~mL}\right)$.

${ }^{\mathrm{b}}$ Calcined at $748 \mathrm{~K}(\mathrm{Si} / \mathrm{Cr}=156)$, benzene $\mathrm{H}_{2} \mathrm{O}_{2}=3(\mathrm{v} / \mathrm{v})$, acetonitrile $(15 \mathrm{~mL})$.

c Benzene (170 mmol), $\mathrm{H}_{2} \mathrm{O}_{2}(55 \mathrm{mmol}, 31 \mathrm{wt} \%)$, gas flow air $(28 \mathrm{~mL} / \mathrm{min})$, acetonitrile $(60 \mathrm{~mL})$.

d Benzene (100 mmol), $\mathrm{H}_{2} \mathrm{O}_{2}$ (30 mmol, $\left.30 \mathrm{wt} \%\right)$, absence of a solvent.

e Not available.

three-dimensional connected channels of SBA-16, which result in high mass transfer of benzene on the Cr/SBA-16 surface. In the present study, for the first time, we optimized benzene hydroxylation to phenol with a $\mathrm{Cr} / \mathrm{SBA}-16$ catalyst using an RSM approach.

The reusability of the Cr/SBA-16 catalyst in the hydroxylation of benzene to phenol was investigated for four runs; the results are shown in Fig. 9. At the end of each run, the catalyst was separated from the reaction mixture by centrifugation, washed with acetonitrile, and dried at $373 \mathrm{~K}$. The recycled catalyst was used under the optimum conditions for the next run. The results show that the phenol yield over the reused catalyst decreased slowly, as a result of loss of catalyst during the reaction and recovery, or leaching of $\mathrm{Cr}$ particles from the extra-framework of the support [30].

\subsection{Proposed mechanism of catalytic reaction}

Heterolytic mechanisms have been proposed for the oxidation of cyclic compounds over modified metal oxides using $\mathrm{H}_{2} \mathrm{O}_{2}$ as the oxidant [40-43]. Based on the proposed reaction mechanisms, we suggest a possible reaction pathway for benzene hydroxylation in the presence of $\mathrm{H}_{2} \mathrm{O}_{2}$ over the $\mathrm{Cr} / \mathrm{SBA}-16$ catalyst (Scheme 2). It is worth mentioning that the mechanism only considers dichromate species as active sites on the catalyst surface. In the first stage, chemisorption of $\mathrm{H}_{2} \mathrm{O}_{2}$ occurs on the surface of the supported $\mathrm{Cr}$, which results in the formation of an open biradical form of a Cr-peroxo complex (Scheme 2(b)). These radicals can coordinate with $\mathrm{Cr}$ in $\mathrm{Cr} / \mathrm{SBA}-16$, to form the

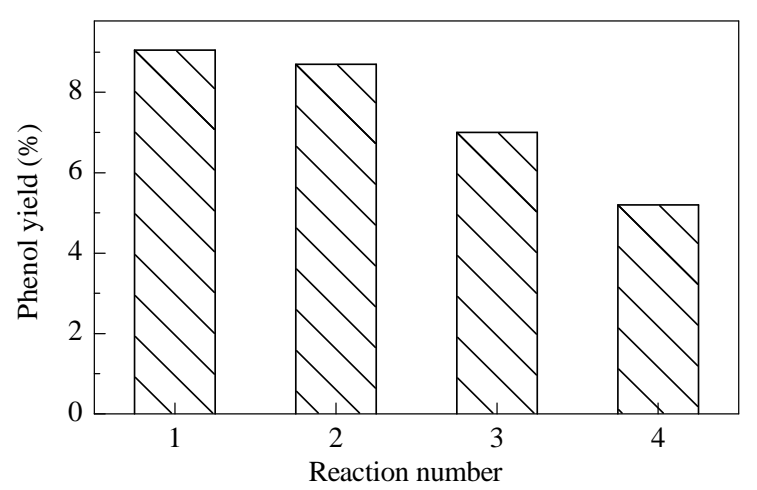

Fig. 9. Reusability of $\mathrm{Cr} / \mathrm{SBA}-16$ under optimized reaction conditions.
Cr-peroxo complex shown in Scheme 2(c). In the second stage, the open biradical form of the $\mathrm{Cr}$-peroxo complex can attack a double bond in a benzene molecule (Scheme 2(d)), to produce a biradical intermediate which is stabilized by transformation to phenol.

\section{Conclusions}

In this study, a chromium nitrate precursor was dispersed on mesoporous silica SBA-16 support using a facile impregnation method (Cr/SBA-16). Wide-angle XRD and UV-vis spectroscopy showed that the major chromium oxides on the support were monochromate, dichromate, and $\mathrm{Cr}_{2} \mathrm{O}_{3}$ phases. The $\mathrm{XRD}, \mathrm{N}_{2}$ adsorption-desorption, and TEM results indicated that the mesoporous structure of the support was retained during catalyst preparation. The catalyst activity in the direct hydroxylation of benzene to phenol using $\mathrm{H}_{2} \mathrm{O}_{2}$ as the oxidant was investigated. Various operating variables of the catalytic reaction, namely reaction temperature, reaction time, amount of $\mathrm{H}_{2} \mathrm{O}_{2}$, and catalyst dosage, were optimized using CCD combined with RSM. The high regression coefficient $\left(R^{2}\right)$, namely 0.983 , implied good agreement between the predicted phenol yield and the experimental results. The optimum conditions were reaction temperature $324 \mathrm{~K}$, reaction time $8 \mathrm{~h}, \mathrm{H}_{2} \mathrm{O}_{2}$ content $3.28 \mathrm{~mL}$, and catalyst dosage $0.09 \mathrm{~g}$. Under these conditions, high phenol selectivity (100\%) was achieved. The results show that RSM is a useful and reliable technique for modeling and optimizing the conditions for hydroxylation of benzene to phenol, with the minimum number of experiments.

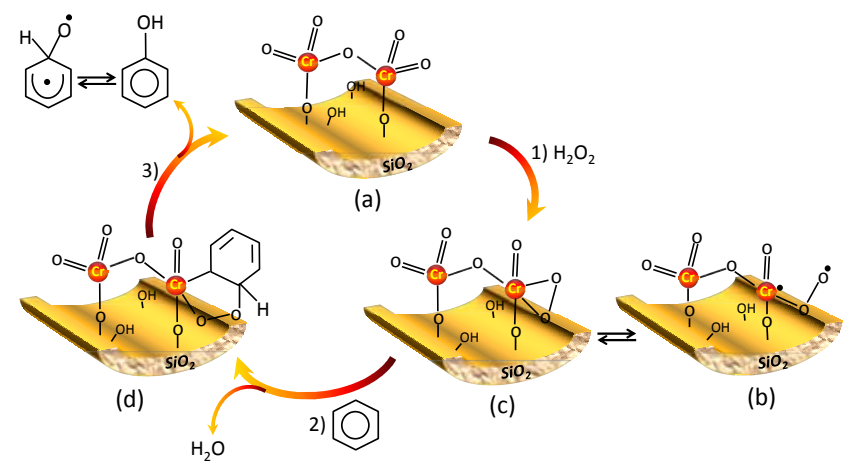

Scheme 2. Catalytic mechanism of benzene hydroxylation by $\mathrm{H}_{2} \mathrm{O}_{2}$ in the presence of $\mathrm{Cr} / \mathrm{SBA}-16$. 


\section{Graphical Abstract}

Chin. J. Catal., 2015, 36: 2020-2029 doi: 10.1016/S1872-2067(15)60898-1

\section{Highly selective production of phenol from benzene over mesoporous silica-supported chromium catalyst: Role of response surface methodology in optimization of operating variables}

Milad Jourshabani, Alireza Badiei*, Negar Lashgari, Ghodsi Mohammadi Ziarani University of Tehran, Iran; Alzahra University, Iran

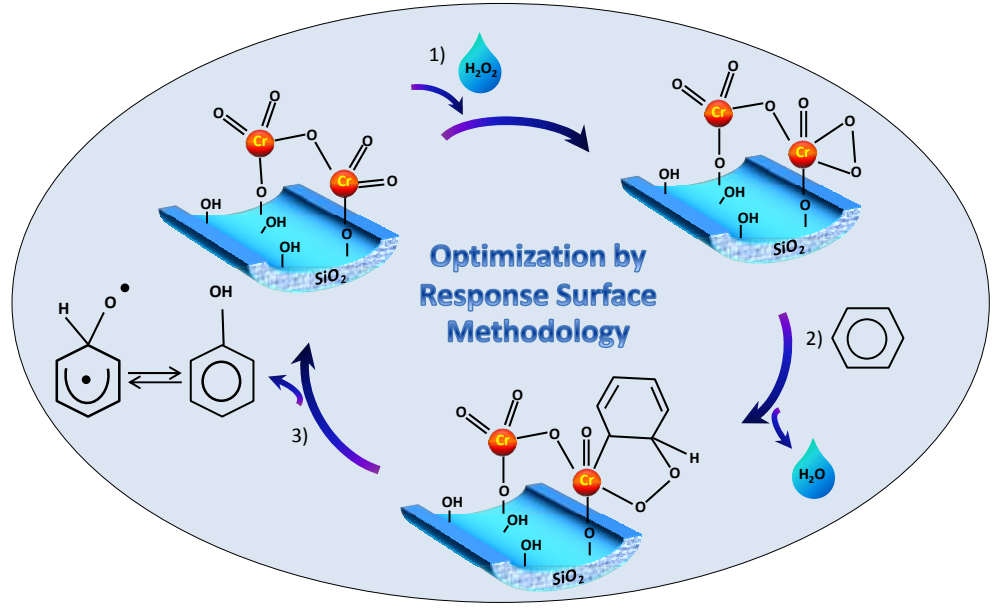

A Cr/SBA-16 catalyst was prepared by an impregnation method and used for the direct hydroxylation of benzene to phenol. This process was modeled using response surface methodology. The catalyst showed high selectivity for phenol under the optimized conditions.

\section{Acknoledgments}

The authors wish to thank the University of Tehran for financial support of this work.

\section{References}

[1] Zhang J, Tang Y, Li G Y, Hu C W. Appl Catal A, 2005, 278: 251

[2] Stöckmann M, Konietzni F, Notheis J U, Voss J, Keune W, Maier W F. Appl Catal A, 2001, 208: 343

[3] Kubacka A, Wang Z L, Sulikowski B, Cortés Corberán V. J Catal, 2007, 250: 184

[4] Pirutko L V, Uriarte A K, Chernyavsky V S, Kharitonov A S, Panov G I. Microporous Mesoporous Mater, 2001, 48: 345

[5] Panov G I, Sheveleva G A, Kharitonov A S, Romannikov V N, Vostrikova L A. Appl Catal A, 1992, 82: 31

[6] Okamura J, Nishiyama S, Tsuruya S, Masai M. J Mol Catal A, 1998, 135: 133

[7] Lee C W, Lee W J, Park Y K, Park S-E. Catal Today, 2000, 61: 137

[8] Lemke K, Ehrich H, Lohse U, Berndt H, Jähnisch K. Appl Catal A, 2003, 243: 41

[9] Jiang T, Wang W T, Han B X. New J Chem, 2013, 37: 1654

[10] Song S Q, Jiang S J, Rao R C, Yang H X, Zhang A M. Appl Catal A, 2011, 401: 215

[11] Arab P, Badiei A, Koolivand A, Mohammadi Ziarani G. Chin J Catal (催化学报), 2011, 32: 258

[12] Xu J, Jiang Q, Chen T, Wu F, Li Y-X. Catal Sci Technol, 2015, 5: 1504

[13] Parida K M, Rath D. Appl Catal A, 2007, 321: 101

[14] Nemati Kharat A, Moosavikia S, Tamaddoni Jahromi B, Badiei A. J Mol Catal A, 2011, 348: 14
[15] Lee C-H, Lin T-S, Mou C-Y.J Phys Chem B, 2003, 107: 2543

[16] Taguchi A, Schüth F. Microporous Mesoporous Mater, 2005, 77: 1

[17] Weitkamp J, Hunger M, Rymsa U. Microporous Mesoporous Mater, 2001, 48: 255

[18] Corma A. Chem Rev, 1997, 97: 2373

[19] Rivera-Muñoz E M, Huirache-Acuña R. Int J Mol Sci, 2010, 11: 3069

[20] Zhu Y J, Dong Y L, Zhao L N, Yuan F L. J Mol Catal A, 2010, 315: 205

[21] Dong Y L, Zhan X L, Niu X Y, Li J, Yuan F L, Zhu Y J, Fu H G. Microporous Mesoporous Mater, 2014, 185: 97

[22] Spinacé E V, Schuchardt U, Cardoso D. Appl Catal A, 1999, 185: L193

[23] Yuvaraj S, Palanichamy M, Krishnasamy V. Chem Commun, 1996: 2707

[24] Tagawa T, Uchida H, Goto S. React Kinet Catal Lett, 1991, 44: 25

[25] Zhang W Z, Wang J L, Tanev P T, Pinnavaia T J. Chem Commun, 1996: 979

[26] Li Y, Wang Z, Chen R Z, Wang Y, Xing W H, Wang J, Huang J. Catal Commun, 2014, 55: 34

[27] Leng Y, Liu J, Jiang P P, Wang J. Chem Eng J, 2014, 239: 1

[28] Xu D, Jia L H, Guo X F. Chin J Catal (徐丹, 贾丽华, 郭祥峰. 催化学 报), 2013, 34: 341

[29] Ding G D, Wang W T, Jiang T, Han B X, Fan H L, Yang G Y. ChemCatChem, 2013, 5: 192

[30] Zhao P P, Leng Y, Wang J. Chem Eng J, 2012, 204-206: 72

[31] Tang Y, Zhang J.J Serbian Chem Soc, 2006, 71: 111

[32] Olutoye M A, Hameed B H. Appl Catal A, 2009, 371: 191

[33] Lazić Ž R. Design and Analysis of Experiments. Section 2.3. New York: Wiley Online Library, 2004

[34] Mason R L, Gunst R F, Hess J L. Statistical Design and Analysis of Experiments: With Applications to Engineering and Science. 2nd Ed. New York: John Wiley \& Sons, 2003

[35] Kosuge K, Kikukawa N, Takemori M. Chem Mater, 2004, 16: 4181 
[36] Hosseinpour V, Kazemeini M, Mohammadrezaee A. Appl Catal A, 2011, 394: 166

[37] Bobet J-L, Desmoulins-Krawiec S, Grigorova E, Cansell F, Chevalier B. J Alloys Compd, 2003, 351: 217

[38] Weckhuysen B M, Wachs I E, Schoonheydt R A. Chem Rev, 1996, 96: 3327

[39] Jian M, Zhu L F, Wang J Y, Zhang J, Li G Y, Hu C W. J Mol Catal A,
2006, 253: 1

[40] Dapurkar S E, Sakthivel A, Selvam P. J Mol Catal A, 2004, 223: 241

[41] Neumann R, Levin-Elad M. Appl Catal A, 1995, 122: 85

[42] Huybrechts D R C, Buskens P L, Jacobs P A.J Mol Catal, 1992, 71: 129

[43] Iwamoto M, Hirata J, Matsukami K, Kagawa S. J Phys Chem, 1983, 87: 903

\section{中孔氧化硅负载铬催化剂上苯高选择性生成苯酚: 响应曲面分析法用于反应条件优化 \\ Milad Jourshabani ${ }^{\text {a }}$, Alireza Badiei ${ }^{\text {a,b,*}}$, Negar Lashgari ${ }^{\text {a }}$, Ghodsi Mohammadi Ziarani ${ }^{\text {c }}$ \\ 德黑兰大学理学院化学学院, 德黑兰, 伊朗 \\ 德黑兰大学纳米科学和纳米技术研究中心, 纳米生物医药杰出研究中心, 德黑兰, 伊朗 \\ ${ }^{\mathrm{c}}$ Alzahra大学理学院化学系, 德黑兰, 伊朗}

摘要: 以硝酸铬为前驱体, 中孔氧化硅SBA-16为载体, 采用简单浸渍法制备了 $\mathrm{Cr} / \mathrm{SBA}-16$ 催化剂, 并采用广角和小角X射线衍射、 $\mathrm{N}_{2}$ 吸附-脱附、透射电镜和紫外-可见光谱等技术对其进行了表征. 同时将该催化剂用于以 $\mathrm{H}_{2} \mathrm{O}_{2}$ 为氧化剂的苯直接羟基化制苯酚反 应以考察其催化性能. 将中心组合设计与响应曲面分析法(RSM)相结合, 对影响反应性能的操作变量如反应温度、反应时间及 $\mathrm{H}_{2} \mathrm{O}_{2}$ 和催化剂用量进行了优化. 结果表明, 独立变量和苯酚产率之间的关系可用二阶多项式模型来表达, 其相关系数 $\left(R^{2}\right)$ 高达 0.985 , 表明用RSM预测的数值与实验值吻合较好. 得到的苯酚选择性较高时的操作条件为: 反应温度 $324 \mathrm{~K}$, 反应时间 $8 \mathrm{~h}, \mathrm{H}_{2} \mathrm{O}_{2}$ 和催化剂用量分别为 $3.28 \mathrm{~mL}$ 和 $0.09 \mathrm{~g}$. 由此可见, 将RSM法用于苯羟基化制苯酚反应条件优化是可靠的.

关键词: 中孔氧化硅; 铬/SBA-16催化剂; 苯羟基化; 苯酚; 响应曲面分析法

收稿日期: 2015-04-23. 接受日期: 2015-05-18. 出版日期: 2015-11-20.

*通讯联系人. 电话: +98-216-1112614; 传真: +98-216-6405141; 电子信箱: abadiei@khayam.ut.ac.ir

本文的英文电子版由Elsevier出版社在ScienceDirect上出版(http://www.sciencedirect.com/science/journal/18722067). 